\title{
Effect of NPK Fertilization on Tachigali vulgaris L. G. Silva \& H. C. Lima Plants
}

\author{
Lenilson Ferreira Palheta ${ }^{1}$, João Olegário Pereira de Carvalho ${ }^{2}$, Alailson Venceslau Santiago ${ }^{3}$, \\ Glauco André dos Santos Nogueira ${ }^{4}$, Vitor Resende do Nasciemento ${ }^{4}$ \& Cândido Ferreira de Oliveira Neto ${ }^{4}$ \\ ${ }^{1}$ Postgraduate Program in Forest Sciences, Federal Rural University of Amazonia, Belém, Pará, Brazil \\ ${ }^{2}$ Institute of Agrarian Sciences, Federal Rural University of Amazônia, Capitão Poço, Pará, Brazil \\ ${ }^{3}$ Embrapa Amazônia Oriental, Belém, Pará, Brazil \\ ${ }^{4}$ Institute of Agrarian Sciences, Federal Rural University of Amazônia, Belém, Pará, Brazil \\ Correspondence: Lenilson Ferreira Palheta, Postgraduate Program in Forest Sciences, Federal Rural University \\ of Amazonia, Belém, Pará, Brazil. E-mail: eng.lenilson@gmail.com
}

Received: March 17, 2019

Accepted: April 26, $2019 \quad$ Online Published: June 30, 2019

doi:10.5539/jas.v11n9p188

URL: https://doi.org/10.5539/jas.v11n9p188

\begin{abstract}
The study on nutritional needs of the tree species T. vulgaris, has a great contribution to the formation and conduction of plantations, resulting in their choice in terms of the potential that has been demonstrated in the comparative trials of fast growing species (more than $0.60 \mathrm{~m} / \mathrm{year}$ in height) and strong regional demand for firewood and coal. The objective of this study was to evaluate the growth of $T$. vulgaris in response to the application of nitrogen, phosphorus and potassium, from the beginning of the establishment until the second year after planting. The study was carried out in the municipality of Igarapé-Açu-PA, in a T. vulgaris plantation of 1.44 ha $\left(14,400 \mathrm{~m}^{2}\right)$, spacing of $2 \mathrm{~m} \times 3 \mathrm{~m}$ (plants $\times$ lines). The treatments consisted in the use of commercial products urea, super triple phosphate and potassium chloride as source of N-nitrogen, phosphorus- $\mathrm{P}_{2} \mathrm{O}_{5}$ and potassium- $\mathrm{K}_{2} \mathrm{O}$ respectively, forming 8 treatmentswhich were analyzed using measures repeated in time. Treatment with combined doses of nitrogen and potassium contributed to a higher growth in height and diameter when compared to plants without fertilization. Fertilization of nitrogen $(26.67 \mathrm{~g})$ plus potassium $(30 \mathrm{~g})$ contributed to a higher planting growth.
\end{abstract}

Keywords: fertilization, nutritional demand, silviculture

\section{Introduction}

Tachigali vulgaris L. G. Silva \& H. C. Lima, synonym of Sclerolobium paniculatum Vogel, popularly known as tachi-branco, comes from South America, with a wide geographic distribution. In Brazil it occurs in the North (Pará, Amazonas and Tocantins), the Northeast (Maranhão, Piauí, Ceará and Bahia), the Midwest (Mato Grosso, Goiás, Distrito Federal and Mato Grosso do Sul) and Southeast (São Paulo and Minas Gerais) (Carvalho, 1994). In order to study the effects of soil fertility on soil erosion, it is important to note that in this case, having stood out by the fast growth, high production of biomass and by the wood to be used as energy source. It is a species that since the 1940s (Le Cointe, 1947) was already considered with characteristics for the production of firewood and charcoal, confirmed later by Paula (1982), and Carpanezzi et al. (1983).

Although plants adapted to the low availability of nutrients can develop, it is indispensable to adopt soil fertility management and correction practices in areas cultivated with tachi-branco, in order to increase the productivity of the forest sites or at least maintain it for (Schumacher et al., 2013; Sousa et al., 2016). These management practices should take into account the adoption of nutrient sources through mineral or organic fertilization (Biagiotti et al., 2017), causing the soil to provide all the nutrients in quantities necessary to obtain the desired growth for the plants (Benites et al., 2010).

For the adequate nutrition of the trees, their demand must be balanced with the supply of nutrients, in time and space, because the characteristics and quantity of fertilizers to be applied will depend on the nutritional needs of the species used, the fertility of the soil, fertilizer efficiency, economic order factors and water availability (Ryan, 2010). 
As a consequence, the importance of carrying out studies involving different doses of fertilization for T. vulgaris, aiming to obtain greater productivity and sustainability in forest production, is based on the appropriate recommendation of the NPK dose. The objective of this study was to evaluate the growth of tachi-branco, in response to the application of nitrogen, phosphorus and potassium, from the beginning of the plantation establishment to the second year after planting.

\section{Material and Methods}

The study area is located at the School Farm of the Federal Rural University of Amazonia-UFRA, in the municipality of Igarapé-Açu (FEIGA). The municipality of Igarapé-Açu belongs to the mesoregion of the Pará Northeast and the Bragantina micro-region. The geographical coordinates of the seat of the municipality are: $01^{\circ} 07^{\prime} 33^{\prime \prime}$ south latitude and $47^{\circ} 37^{\prime} 27^{\prime \prime}$ longitude west of Greenwich.

The work was carried out in an one-year old T. vulgaris plantation of 1.44 ha $\left(14,400 \mathrm{~m}^{2}\right)$, implanted on February 1, 2016, with a spacing of $2 \mathrm{~m} \times 3 \mathrm{~m}$ (plants $\times$ lines), as recommended by Souza et al. (2016), totaling 1,728 plants distributed in lines, in the East-West direction.

In order to support decision-making regarding fertilizer/treatment applications, soil samples were collected randomly throughout the planting area, prior to their implantation, at 0-20 and 20-40 cm depths of the soil, which consisted of two composite samples, which were then sent to the laboratory, where they were submitted to chemical and physical analysis (Tables 1 and 2). Although the acidity levels according to Table 1 were considered high (Raij, 1991), we decided not to add calcareous to correct the soil.

Table 1. Soil chemical characterization of the planting area

\begin{tabular}{|c|c|c|c|c|c|c|c|c|c|c|c|c|}
\hline Identification & $\mathrm{P}$ & $\mathrm{OM}$ & $\mathrm{pH}$ & $\mathrm{K}$ & $\mathrm{Ca}$ & $\mathrm{Mg}$ & $\mathrm{H}+\mathrm{Al}$ & $\mathrm{Al}$ & SB & $\mathrm{T}$ & $\mathrm{V}$ & $\mathrm{m}$ \\
\hline & $\mathrm{mg} \mathrm{dm}^{-3}$ & $\mathrm{~g} \mathrm{dm}^{-3}$ & $\mathrm{CaCl}_{2}$ & \multicolumn{7}{|c|}{ 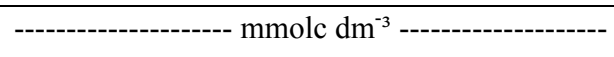 } & \multicolumn{2}{|c|}{------ \% ------- } \\
\hline $0-20$ & 2.3 & 18 & 4.3 & 0.4 & 5 & 1 & 38 & 5 & 6,9 & 44.9 & 15 & 42.0 \\
\hline $20-40$ & 2.4 & 15 & 4.3 & 0.4 & 4 & 1 & 30 & 7 & 6,1 & 36.1 & 17 & 53.4 \\
\hline
\end{tabular}

Table 2. Soil physical analysis of the planting area

\begin{tabular}{|c|c|c|c|c|}
\hline Depth $(\mathrm{cm})$ & Clay & Silt & Total sand & Silt + Clay \\
\hline & \multicolumn{4}{|c|}{ 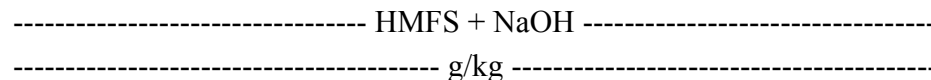 } \\
\hline $0-20$ & 184 & 90 & 726 & 274 \\
\hline $20-40$ & 225 & 111 & 664 & 336 \\
\hline
\end{tabular}

Note. Obs: HMFS (sodium hexametaphosphate $\left[\mathrm{Na}_{6}\left(\mathrm{PO}_{3}\right)_{6}\right]$ ) and $\mathrm{NaOH}$ (sodium hydroxide) were the industrial dispersants used by the laboratory to determine the physical analysis of the soil.

The treatments followed average doses of fertilizers found in the literature for forest stands such as eucalyptus and black acacia (Costa et al., 2012; Schumacher et al., 2013), which consisted in the use of commercial products, urea, triple super phosphate and potassium chloride as nitrogen-N, phosphorous- $\mathrm{P}_{2} \mathrm{O}_{5}$ and potassium $-\mathrm{K}_{2} \mathrm{O}$ respectively, forming the treatments (Table 3 ). Those were combined according to the fractional factorial arrangement 23 at random, represented by 8 treatments with plots of 4 plants and 4 replications, randomly installed at the planting, totaling 128 plants studied.

Table 3. Treatments and their respective dosages of commercial fertilizer in grams per plant

\begin{tabular}{llllll}
\hline Treatment/Fertilization & Combinations & Urea $(\mathrm{g})$ & Triple superphosphate $(\mathrm{g})$ & Potassium chloride $(\mathrm{g})$ & $\mathrm{Kg} / \mathrm{ha}$ \\
\hline T0 & Control & 0 & 0 & 0 & 0 \\
T1 & N & 26.67 & 0 & 0 & 44.5 \\
T2 & P & 0 & 19.56 & 0 & 32.6 \\
T3 & K & 0 & 0 & 30 & 50 \\
T4 & NP & 26.67 & 19.56 & 0 & $44.5(\mathrm{~N})+32.6(\mathrm{P})$ \\
T5 & NK & 26.67 & 0 & 30 & $44.5(\mathrm{~N})+50(\mathrm{~K})$ \\
T6 & PK & 0 & 19.56 & 30 & $32.6(\mathrm{P})+50(\mathrm{~K})$ \\
T7 & NPK & 26.67 & 19.56 & 30 & $44.5(\mathrm{~N})+32.6(\mathrm{P})+50(\mathrm{~K})$ \\
\hline
\end{tabular}


The treatments were established one year after the planting of tachi-branco. A cover fertilization was applied, just once, around the plants, but $10 \mathrm{~cm}$ away from them, considering the dosages in Table 3 .

The diameter and height of the plants used for growth analysis were measured every three months since the establisment of the treatments, from June 2017 to June 2018, totaling 5 measurements.

The diameter of the plants was measured at the DBH (diameter at breast height), that means measured at 1.3 meter from the ground, using a centimetrical diameter tape. The total height of the plants was measured with a ruler graduated in centimeters.

In order to analyse the plant growth rate in the treatments, the data were submitted to anormality test, then an analysis of variance was performed, considering measures repeated in time. Further, gas exchange analyzes were performed in order to find out if the applied nutrients were absorbed by T. vulgaris plants. Measurements for gas exchange analyzes were performed from 9 am to 11 am between the plants in each treatment, in fully expanded and completely mature leaves. An infrared gas analyzer (IRGA Infrared Gas Analizer), model Li-6400 (Li-Cor, Biosciences Inc., Nebraska, EUA) was used to determine the Net photosynthetic rate per unit of leaf area (A, $\mu \mathrm{mol} \mathrm{CO} \mathrm{Cm}_{2} \mathrm{~m}^{-2} \mathrm{~s}^{-1}$ ), the stomatal conductance to water vapor (gs, mol $\mathrm{H}_{2} \mathrm{O} \mathrm{m}^{-2} \mathrm{~s}^{-1}$ ) and the transpiratory rate (E, $\mathrm{mmol} \mathrm{H}_{2} \mathrm{O} \mathrm{m}^{-2} \mathrm{~s}^{-1}$ ).

\section{Results}

\subsection{Height}

The treatments nitrogen ( $\mathrm{t} 1$ ), phosphorus ( $\mathrm{t} 2$ ) and potassium ( $\mathrm{t} 3$ ) and the combination of $\mathrm{N}: \mathrm{K}(\mathrm{t} 5)$ had significant statistical effect for total height of $T$. vulgaris plants. The time of evaluation did not influence positively on the plants growth. The mean growth in the last measurement in each treatment was: t1 $(603 \mathrm{~cm}), \mathrm{t} 2(537 \mathrm{~cm}), \mathrm{t} 3$ $(581 \mathrm{~cm}), \mathrm{t} 5(596 \mathrm{~cm})$, as shown in Table 4.

Table 4. Height growth $(\mathrm{cm})$ of T. vulgaris according to fertilization treatments: T0-control, T1-nitrogen (N), T2-phosphor (P), T3-potassium (K) and their combinations (T4-NP, T5-NK, T6-NP, and T7-NPK) and interaction with the time $(\mathrm{t})$ of growth, corresponding to 12 months of experimentation

\begin{tabular}{llllll}
\hline \multirow{2}{*}{ Treatments } & \multicolumn{5}{c}{ Time } \\
\cline { 2 - 6 } & 0 & 1 & 2 & 3 & 4 \\
\hline T0 (Control) & $247 \mathrm{a}$ & $324 \mathrm{a}$ & $368 \mathrm{a}$ & $426 \mathrm{a}$ & $503 \mathrm{a}$ \\
T1 $(26.67 \mathrm{~g}$ urea $) * * *$ & $307 \mathrm{~b}$ & $403 \mathrm{~b}$ & $465 \mathrm{~b}$ & $534 \mathrm{~b}$ & $603 \mathrm{~b}$ \\
T2 $(19.56 \mathrm{~g} \mathrm{SFT}) * * *$ & $275 \mathrm{bc}$ & $357 \mathrm{bc}$ & $405 \mathrm{bc}$ & $471 \mathrm{bc}$ & $537 \mathrm{bc}$ \\
T3 $(30 \mathrm{~g} \mathrm{KCL}) * *$ & $282 \mathrm{bcd}$ & $374 \mathrm{bcd}$ & $428 \mathrm{bcd}$ & $499 \mathrm{bcd}$ & $581 \mathrm{bcd}$ \\
T4 $(26.67 \mathrm{~g}$ urea $+19.56 \mathrm{~g} \mathrm{SFT})$ & $336 \mathrm{e}$ & $431 \mathrm{e}$ & $487 \mathrm{e}$ & $562 \mathrm{e}$ & $639 \mathrm{e}$ \\
T5 $(26.67 \mathrm{~g}$ urea $+30 \mathrm{~g} \mathrm{KCL}) * * *$ & $304 \mathrm{ef}$ & $407 \mathrm{bef}$ & $467 \mathrm{bef}$ & $536 \mathrm{bef}$ & $596 \mathrm{bef}$ \\
T6 $(19.56 \mathrm{~g} \mathrm{SFT}+30 \mathrm{~g} \mathrm{KCL})$ & $333 \mathrm{~g}$ & $441 \mathrm{eg}$ & $495 \mathrm{eg}$ & $576 \mathrm{~g}$ & $654 \mathrm{~g}$ \\
T7 $(26.67 \mathrm{~g}$ urea $+19.56 \mathrm{~g} \mathrm{SFT}+30 \mathrm{~g} \mathrm{KCL})$ & $315 \mathrm{befg}$ & $416 \mathrm{efg}$ & $470 \mathrm{befg}$ & $531 \mathrm{befg}$ & $602 \mathrm{befg}$ \\
\hline
\end{tabular}

Note. Levels of significance, $* * * 0.1 \% ; * * 1 \% ; 5 \%$. Differente Letters in the same column differ between treatments and on the same line differ in time.

\section{Diameter}

Of the fertilizer sources that had a positive developmental effect in diameter, only N, P and K, and N:P and N:K combinations were statistically significant (Table 5). The development over time to diameter was also similar to height, with no statistical significance during the two years and 3 months of analysis, being the difference between treatments, visible at the end of the first year of the study implantation. The plants in the in the treatments with significant difference had mean diameter of $24.5 ; 21.0 ; 23.1 ; 24.3 ; 24.8 \mathrm{~cm}$ for T1, T2, T3, T4 and $\mathrm{T} 5$ respectively. 
Table 5. Mean diameter growth $(\mathrm{cm})$ of T. vulgaris in the treatments according to fertilization: T0-control, T1-nitrogen $(\mathrm{N})$, T2-phosphor $(\mathrm{P})$, T3-potassium $(\mathrm{K})$ and their combinations (T4-NP, T5-NK, T6-NP, and T7-NPK) and interaction with the time $(\mathrm{t})$ of growth, corresponding to 12 months of experimentation

\begin{tabular}{llllll}
\hline \multirow{2}{*}{ Treatments } & \multicolumn{5}{c}{ Time } \\
\cline { 2 - 6 } & 0 & 1 & 2 & 3 & 4 \\
\hline T0 (control) & $8.0 \mathrm{a}$ & $11.3 \mathrm{a}$ & $13.6 \mathrm{a}$ & $17.4 \mathrm{a}$ & $20.4 \mathrm{a}$ \\
T1 $(26.67 \mathrm{~g}$ urea $) * * *$ & $10.2 \mathrm{abc}$ & $14.7 \mathrm{abc}$ & $17.9 \mathrm{abc}$ & $21.5 \mathrm{abc}$ & $24.5 \mathrm{abc}$ \\
T2 $(19.56 \mathrm{~g} \mathrm{SFT}) *$ & $8.1 \mathrm{ab}$ & $12.6 \mathrm{ab}$ & $14.8 \mathrm{ab}$ & $18.1 \mathrm{ab}$ & $21.0 \mathrm{ab}$ \\
T3 $(30 \mathrm{~g} \mathrm{KCL}) * * *$ & $9.5 \mathrm{abc}$ & $13.6 \mathrm{abc}$ & $16.3 \mathrm{abc}$ & $20.0 \mathrm{abc}$ & $23.1 \mathrm{abc}$ \\
T4 $(26.67 \mathrm{~g}$ urea $+19.56 \mathrm{~g} \mathrm{SFT}) *$ & $11.4 \mathrm{bc}$ & $15.9 \mathrm{bc}$ & $18.3 \mathrm{bc}$ & $21.5 \mathrm{bc}$ & $24.3 \mathrm{bc}$ \\
T5 $(26.67 \mathrm{~g}$ urea $+30 \mathrm{~g} \mathrm{KCL}) * * *$ & $10.6 \mathrm{bc}$ & $15.4 \mathrm{bc}$ & $17.9 \mathrm{bc}$ & $21.7 \mathrm{bc}$ & $24.8 \mathrm{bc}$ \\
T6 $(19.56 \mathrm{~g}$ SFT $+30 \mathrm{~g} \mathrm{KCL})$ & $11.1 \mathrm{c}$ & $16.8 \mathrm{c}$ & $19.5 \mathrm{c}$ & $23.9 \mathrm{c}$ & $27.3 \mathrm{c}$ \\
T7 $(26.67 \mathrm{~g}$ urea $+19.56 \mathrm{~g} \mathrm{SFT}+30 \mathrm{~g} \mathrm{KCL})$ & $11.3 \mathrm{bc}$ & $15.5 \mathrm{bc}$ & $17.8 \mathrm{bc}$ & $20.8 \mathrm{bc}$ & $23.4 \mathrm{bc}$ \\
\hline
\end{tabular}

Note. Levels of significance, $* * * 0.1 \%$;* $1 \%$; $5 \%$. Different letters in the same column differ between treatments and on the same line differ in time.

\subsection{Gas Exchange}

The results of gas exchange analyzes showed that fertilizers that had a significant effect on both height and diameter promoted a photosynthetic rate of 7.2136 (T1), 8.5293 (T2), 5.5617 (T3) and $16.5654 \mu \mathrm{mol} \mathrm{CO}_{2} \mathrm{~m}^{-2} \mathrm{~s}^{-1}$ (T5), to which of these, treatment 5 had a higher mean followed by T4, whose fertilization contributed only to the growth in diameter. The stomatal conductance and transpiratory rate had similar results for all treatments.

Table 6. Average analysis of gas exchange of plants with fertilization treatments. A (net photosynthetic rate per unit leaf area); gs (stomatal conductance to water vapor): E (transpiratory rate)

\begin{tabular}{llll}
\hline Treatments & $\mathrm{A}\left(\mu \mathrm{mol} \mathrm{CO} \mathrm{m}^{-2} \mathrm{~s}^{-1}\right)$ & $\mathrm{gs}_{\left(\mathrm{mol} \mathrm{H}_{2} \mathrm{O} \mathrm{m}^{-2} \mathrm{~s}^{-1}\right)}$ & $\mathrm{E}\left(\mathrm{mmol} \mathrm{H}_{2} \mathrm{O} \mathrm{m}^{-2} \mathrm{~s}^{-1}\right)$ \\
\hline T0 (witness) & 3.38 & 0.35 & 5.65 \\
T1 $(26.67$ g urea $)$ & 7.21 & 0.07 & 4.15 \\
T2 $(19.56$ g SFT $)$ & 8.53 & 0.10 & 5.50 \\
T3 (30 g KCL) & 5.56 & 0.08 & 4.49 \\
T4 (26.67 g urea + 19.56 g SFT) & 4.89 & 0.08 & 4.42 \\
T5 (26.67 g urea + 30 g KCL) & 16.57 & 0.08 & 4.61 \\
T6 (19.56 g SFT + 30 g KCL) & 12.05 & 0.09 & 5.30 \\
T7 $(26.67$ g urea +19.56 g SFT + 30 g KCL $)$ & 6.72 & 0.09 & 5.23 \\
\hline
\end{tabular}

\section{Discussion}

\subsection{Growth in Height}

T. vulgaris plants showed a growth rate (Figure 1) that promoted increase between time zero and time five of $296 \mathrm{~cm}$ with the application of $26.67 \mathrm{~g}$ of urea per plant or $44.5 \mathrm{~kg} \mathrm{ha}^{-1}$. As in this study, Ciriello et al. (2014) evaluated the effect of nitrogen doses on the initial development and nutrition of Guanandi plants (Calophyllum brasiliense Cambèss), native tree species from Brazil, to which they applied five doses of N: 0, 178, 356, 533 and $711 \mathrm{~kg} \mathrm{ha}^{-1}$ of urea, plus the control (without fertilization); they concluded that the dose of urea at $178 \mathrm{~kg}$ $\mathrm{ha}^{-1}$ at the time of planting is enough to supply the need for nitrogen in the initial growth of guanandi, being 4 times greater than the amount of fertilizer used in the present study ( $44.5 \mathrm{~kg} \mathrm{ha}^{-1}$ of urea). 


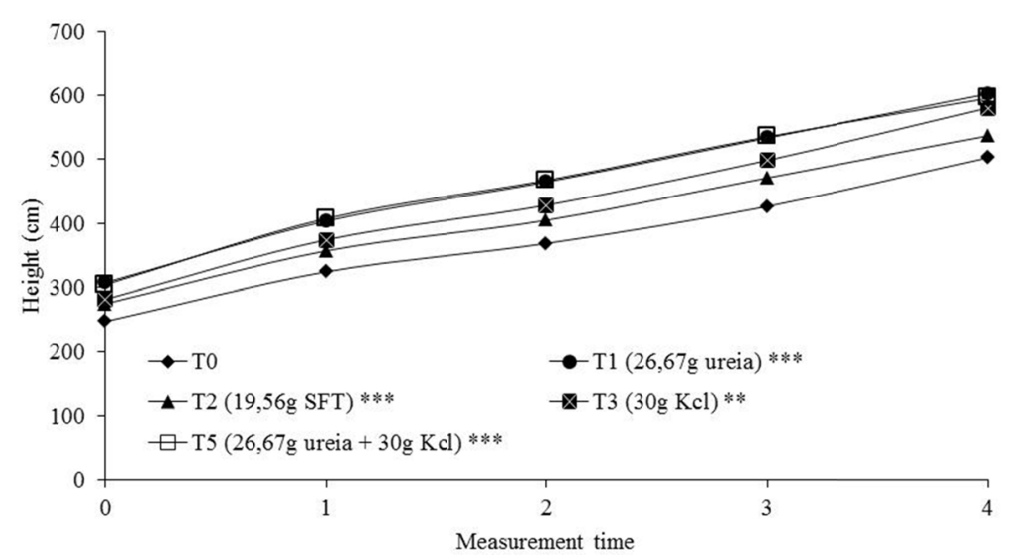

Figure 1. Growth in height of $T$. vulgaris plants with application of nitrogen fertilization doses (T1-application of $26.67 \mathrm{~g}$ of urea per plant or $44.5 \mathrm{~kg} \mathrm{ha}^{-1}$ ), phosphate (T2-application of $19.56 \mathrm{~g}$ of triple superphosphate per plant), potassium (T3-application of $30 \mathrm{~g}$ of potassium chloride per plant or $50 \mathrm{~kg} \mathrm{ha}^{-1}$ ), nitrogen + potassium (T5-application of $26.67 \mathrm{~g}$ of urea $+30 \mathrm{~g}$ of potassium chloride per plant or 44.5 and $50 \mathrm{~kg} \mathrm{ha}^{-1}$ respectively) and without fertilization-T0, throughout the measurement time

Fertilization with phosphorus (P) promoted growth of $34 \mathrm{~cm}$ more than when correlated with plants without the addition of nutrients (Figure 1). This response to mineral fertilization with $\mathrm{P}$, results from the low available content of this element in soil $\left(2.3 \mathrm{mg} \mathrm{dm}^{-3}\right)$ according to the classes proposed by Raij (1991), which is an essential element for the growth of plants, and their deficiency is often reported in weathered tropical soils (Rodrigues et al., 2016). The supply of calcium via triple superphosphate (12 to $14 \%$ of the mineral fertilizer is composed of $\mathrm{Ca}$ ) may also have contributed. Tachi branco plants probably showed marked responses to the addition of calcium via triple superphosphate, since the exchangeable content of this element in the soil was below (Table 1) the lower supply limit $\left(20.0 \mathrm{mmolc} \mathrm{dm}^{-3}\right)$ and, furthermore, soil acidity correction was not performed by calcareous application.

Another factor that may have contributed to the development of the height of the forest stand that received $\mathrm{P}$ fertilization is the fact that the tachi-branco species is tolerant to soils with high acidity (Lima, 2004; Oliveira et al., 2006). The increased acidity causes reduced availability of phosphorus to plants. In soils with $\mathrm{pH}$ in $\mathrm{H}_{2} \mathrm{O} \leq$ $5.5, \mathrm{Al}^{3+}$ is in the trivalent ionic form that is toxic to plants (Ciamporová, 2002). Levels of naturally occurring $\mathrm{Al}^{3+}$ in acid soils range from 10 to $100 \mu \mathrm{M}$, sufficient for immediate and severe inhibition of root growth of the species (Epstein \& Bloom, 2006). The physiological basis of the damage caused by $\mathrm{Al}^{3+}$ is not yet completely elucidated, however, it is known that this ion is strongly associated with many oxygen donor ligands, such as carboxylic groups, phosphates and sulphates; consequently interact with cell walls, plasma membranes, proteins and nucleotides (Epstein \& Blomm, 2006). As a consequence, there is a considerable reduction and/or paralysis of the cell division of the apical meristem of the roots, resulting in a drastic decrease in cell elongation (Rout et al., 2001; Yamamoto et al., 2002). In addition, the reduction of the root system affects the absorption, mainly of the P, since this nutrient is dislocated in the soil by diffusion (Lukowiak et al., 2016; Frazão et al., 2019).

Potassium (K) also had a high significance in the growth in height (Table 4). This fact must also be present in several physiological functions of plants such as: enzymatic activation, protein synthesis, photosynthesis, as well as a clear function in the processes of opening and stomatal closure (Silva et al., 2011). Figure 1 shows the development of the plants that received fertilization with potassium, in which the difference in height growth, with an increase of $78 \mathrm{~cm}$ in relation to the plants that did not receive nutrients, is visible. In E. saligna, the application of $140 \mathrm{~kg} \mathrm{ha}^{-1}$ of $\mathrm{K}_{2} \mathrm{O}$ in sandy texture Oxisols, provided an increase of $3.7 \mathrm{~m}$ in plant height at 36 months compared to plants that did not receive fertilization (Laclau et al., 2009).

Potassium (K) is the second nutrient most absorbed by plants, being essential in the activation of several enzymes that act in the processes of photosynthesis and respiration. In tropical soils the potassium contents normally found are considered low $\left(<1.5 \mathrm{mmol} \mathrm{dm}^{-3}\right)$, as in this study $(0.4 \mathrm{mmolc} \mathrm{dm})$, requiring the use of potassium fertilization fertilizers for supplementation (Benites et al. 2010). Their deficiency may lead to a reduction in apical dominance and in plant growth, as well as to retard fruiting and produce smaller fruits with less color (Costa et al., 2017). 
The combination of nitrogen and potassium $(\mathrm{N}: \mathrm{K})$ promoted a $93 \mathrm{~cm}$ increase in height of the plants that received fertilization in relation to the control corresponding to the last measurement (Figure 1). Jesus et al. (2016) found similar results for Eucalytpus globulus seedlings, concluding that fertilization, with nitrogen and potassium, influenced the initial growth of the seedlings, being an important factor in the plant growth in the seedling stage for all levels studied. The height, considered a morphological characteristic of quality and vigor of seedlings, is used to express the potential of development, both in the field and in nurseries, in this way, both the nitrogen and potassium application is fundamental for obtaining planting of tachi-branco of better silvicultural quality (Figure 4).

\subsection{Diameter Growth}

Nitrogen fertilization treatment ( $26.67 \mathrm{~g}$ of urea) had a highly significant effect on the development in diameter (Table 5) of the tachi-branco plants, being visible in Figure 2, with an increase of $4 \mathrm{~cm}$ in relation to the control in the time five. Native species present different nutritional requirements, which make it difficult to transfer experiences, but these can be used to guide studies with little studied essences among them the tachi branco. For example, Nascimento et al. (2014) determined that for jatobá (Hymenaea courbaril L.) the diameter of the stem of plants with no nitrogen application showed reductions of $21 \%$ in relation to individuals that received the nutrient, being the diameter less affected by the effects of short-term nutritional suppression, these reductions were only possible to observe from the 70th day. These authors also observed that $\mathrm{N}$ was the macronutrient most limiting to the growth of jatobá plants, suggesting that the nutritional requirement for the macronutrients of this species obeys the decreasing order of: $\mathrm{N}>\mathrm{P}>\mathrm{K}$.

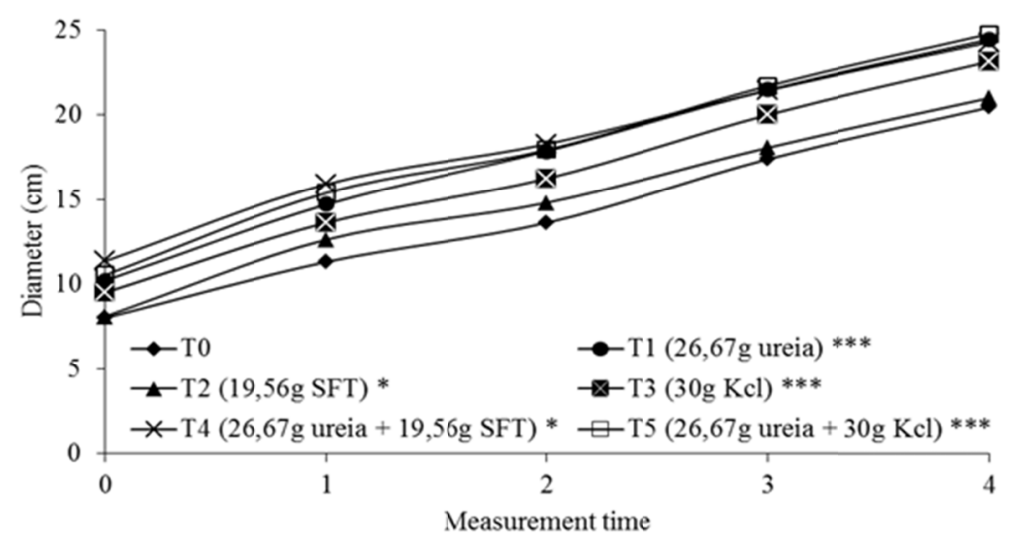

Figure 2. Growth in diameter of T. vulgaris plants under doses of nitrogen fertilization (T1-application of 26.67 $\mathrm{g}$ of urea per plant or $44.5 \mathrm{~kg} \mathrm{ha}^{-1}$ ), phosphate (T2-application of $19.56 \mathrm{~g}$ of superphosphate or $32.6 \mathrm{~kg} \mathrm{ha}^{-1}$ ), potassium (T3-application of $30 \mathrm{~g}$ of potassium chloride per plant or $50 \mathrm{~kg} \mathrm{ha}^{-1}$ ), nitrogen + phosphorus (T4-application of $26.67 \mathrm{~g}$ urea $+19.56 \mathrm{~g} \mathrm{SFT}$ or $44.5+32.6 \mathrm{~kg} \mathrm{ha}^{-1}$, respectively), nitrogen + potassium (T5-application of $26.67 \mathrm{~g}$ of urea $+30 \mathrm{~g}$ of potassium chloride per plant or 44.5 and $50 \mathrm{~kg} \mathrm{ha}^{-1}$ respectively) and without fertilization-T0, over the measurement time

At a Pinus taeda plantation, evaluated at five years of age, Moro et al. (2014) observed that the application of nitrogen in a harmful way did not influence the diameter development. The authors concluded that the rate of $\mathrm{N}$ applied did not differ statistically from each other in terms of tree diameter increase, and the highest dose applied was $140 \mathrm{~kg} \mathrm{ha}^{-1}$ of $\mathrm{N}$, higher than that used in the present study.

As for height, phosphorus fertilization (T2-19.56 g SFT) contributed to growth in diameter of the tachi-branco plants, increasing $1 \mathrm{~cm}$ more than those plants without addition of nutrients (Figure 2).

The calcium supply via triple superphosphate (12 to $14 \%$ of the mineral fertilizer is composed of Ca) may also have contributed to the positive effect of P. In Eucalyptus camaldulensis trees, phosphate fertilization promoted a higher diameter growth, with a maximum value of $5.6 \mathrm{~cm}$ at a $\mathrm{P}$ application dose of $120 \mathrm{~kg} \mathrm{ha}^{-1}$ in relation to the control (Costa et al., 2012).

The application of potassium (K) promoted growth in diameter of the plantation (Figure 2) contributing with increment of $3 \mathrm{~cm}$ in relation to the control. Biagiotti et al. (2017) studying potassium fertilization in a Corymbia citriodora planting at $6,9,12$ and 24 months after planting, observed that at 12 months there was a quadratic 
effect of treatments and maximum growth $(5.98 \mathrm{~cm})$ was estimated with the dose of $62 \mathrm{~kg} \mathrm{ha}^{-1}$ of $\mathrm{K}_{2} \mathrm{O}$. At 24 months, there was no effect of treatments, concluding that up to 12 months of age, growth and biomass production of $C$. citriodora were favored by potassium fertilization.

The combination of $\mathrm{N}: \mathrm{P}$ and $\mathrm{N}: \mathrm{K}$ fertilizer sources were significant at 5 and $0.1 \%$ of error probability, respectively (Figure 2). This may have occurred because of the synergistic effect of the interaction of such nutrients. This represented a growth in diameter of $4 \mathrm{~cm}$ for the treatment with $\mathrm{N}: \mathrm{P}$ and $5 \mathrm{~cm}$ for the treatment $\mathrm{N}: \mathrm{K}$ in the last measurement (12 months) higher than the control (Figure 2), being the fertilization with $\mathrm{N}: \mathrm{K}$ better among them.

P deficiency reducing $\mathrm{N}$ absorption has been observed in some studies. Santos et al. (2015) evaluated the efficiency of nitrogen fertilization by genotypes of tree cotton under phosphorus application, observed that genotypes grown in low $\mathrm{P}$ supply had higher leaf $\mathrm{N}$ concentration, indicating a synergism ratio between $\mathrm{N}$ and $\mathrm{P}$. This corroborates with the present study, since the interaction between nitrogen and phosphorus was positive for the growth in diameter of the plants (Figure 2). The $\mathrm{P}$ interferes in the absorption of $\mathrm{N}$ indirectly, through the reduction of the leaf area (Santos et al., 2015). The leaf area is closely related to $\mathrm{N}$ absorption, because the larger the leaf area, the higher the transpiration rate, which in turn increases the flow of water absorbed by the plant, which directly influences the nutrients from soil to the root surface, being significant for N (Bonfim-Silva \& Monteiro, 2010; Han et al., 2015).

The treatment with nitrogen and potassium fertilization promoted a higher diameter growth of $T$. vulgaris. In soils with high $\mathrm{K}$ contents, $\mathrm{N}$ stimulates vegetative growth, increasing the $\mathrm{K}$ content in the aerial part of the plants and consequently, the utilization of the nutrient reserves in the soil solution. Potassium plays a key role in the functioning of the enzymes necessary for the growth and development of the plant; it also helps in the absorption of nitrogen, which results in better vegetative growth (Debbarma et al., 2017).

In eucalyptus plantations in sandy lands the highest responses to nitrogen and potassium fertilization occurred in the first year of tree growth, with application of 4.3 and $20 \mathrm{~kg} \mathrm{ha}^{-1}$ of the respective nutrients, suggesting that the number of $\mathrm{N}$ and $\mathrm{K}$ applications may be reduced after planting for establishment of commercial plantations without adversely affecting productivity and deeper drainage losses (Silva et al., 2013). Jesus et al. (2016) studying the growth and chemical composition of the essential oil of Eucalyptus globulus seedlings fertilized with nitrogen and potassium found similar results, concluding that fertilization with nitrogen and potassium influenced the initial growth of the seedlings, increasing in $72 \%$ the diameter of the plants that received NK fertilization in relation to the control.

\subsection{Gas Exchange}

The results of the gas exchange analyzes (Table 6) are mainly explained, because the nitrogen and potassium are present in the photosynthetic process. $\mathrm{N}$ is involved in carbon assimilation due to the enzymes involved in the carbon sequestration process (Marschner, 2012). $\mathrm{N}$ is required for the synthesis of chlorophyll, which in turn participates in the measurement of the efficiency of photochemical reactions of photosynthesis as the primary receptor molecule of electrons in photosystem II after the oxidation of water mediated by light; the flow of these electrons between photosystems I and II on the thylakoid membrane; thermal dissipation within the PSII and the quantum efficiency of electron transfer for the formation of the NADPH, ATP and Fdr reductant used in the assimilation of $\mathrm{CO}_{2}$ in the biochemical phase of photosynthesis (Rohácek, 2002; Baker, 2008).

Gomes (2012) evaluated the effect of fertilization and acidity correction on homogenous planting of Bertholletia excelsa H.B. and concluded that nitrogen fertilization showed direct reflexes, with increases on the nutritional status of young plants of $B$. excelsa, however, there were no differences among the treatments for photosynthesis, transpiration rates and stomatal conductance. This result was opposite to results of the present study, where T5 treatment (26.67 g urea $+30 \mathrm{~g} \mathrm{KCL}$ per plant) had a higher photosynthetic rate (Figure 3). 


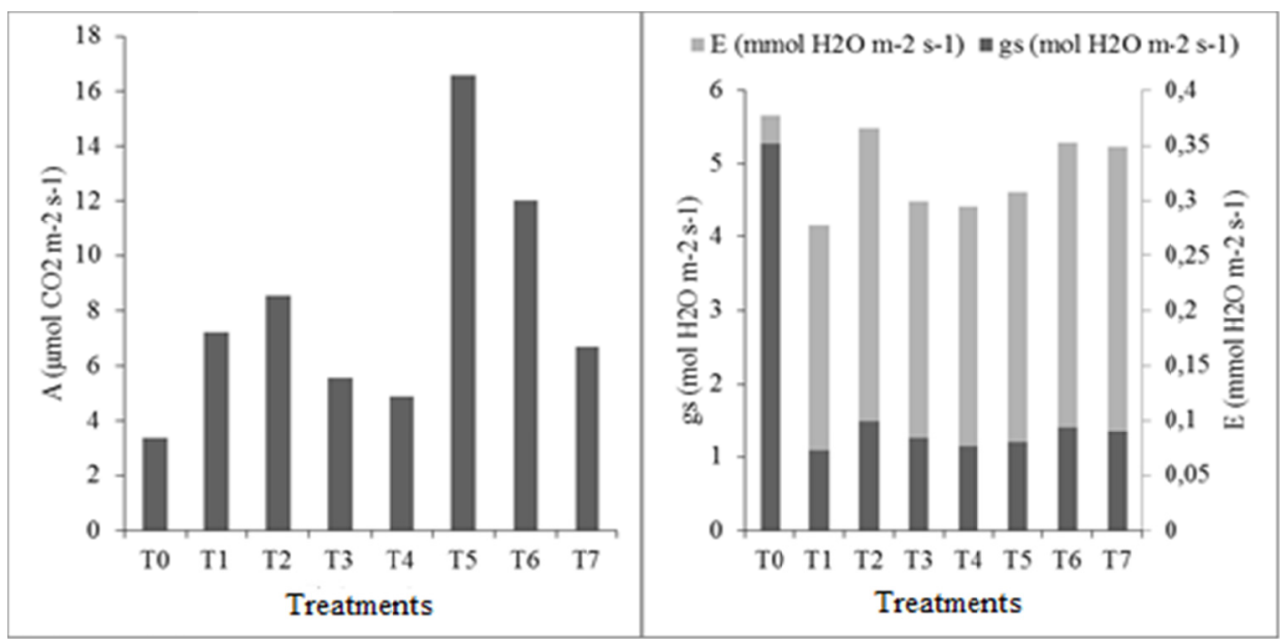

Figure 3. Analysis of gas exchange of plants with fertilization treatments, in the last dendrometric measurement. A (net photosynthetic rate per unit of leaf area); gs (stomatal conductance to water vapor); E (transpiratory rate)

Potassium also performs its physiological functions in opening and closing stomata by controlling the water potential of cells (Marschner, 2012). The $\mathrm{K}^{+}$cation facilitates the transport of $\mathrm{NO}_{3}{ }^{-}$from root to stem (Mengel \& Kirkby, 2001). This element presents some functions in physiological terms as it actively participates in the release of the sucrose molecules produced in the photosynthetic process, from the cells of the mesophyll to the apoplast (Magalhães, 2007).

The physiological characteristics of eucalyptus genotypes under the effect of potassium supply in two conditions of water availability showed that potassium fertilization can attenuate the negative effects of water deficiency in the initial stages of growth of the tested genotypes, which presented better physiological performances than those without potassium fertilization, presenting better stomatal control and, consequently, higher values of $\mathrm{A}$ and $\mathrm{E}$ (Mendes et al., 2013).

\section{Conclusion}

The combined dose of nitrogen and potassium contributed to the better growth of height and diameter of $T$. vulgaris plants. It is recommended therefore the combined fertilization of nitrogen and potassium in the doses of 26.67 and $30 \mathrm{~g}$ per plant respectively or $44.5 \mathrm{~kg} / \mathrm{ha}$ of urea and $50 \mathrm{~kg} / \mathrm{ha}$ of potassium, from the second year after planting.

\section{References}

Baker, N. R. (2008). Chlorophyll fluorescence: A probe of photosynthesis in vivo. Annual Review of Plant Biology, 59, 89-113. https://doi.org/10.1146/annurev.arplant.59.032607.092759

Benites, V. M., Carvalho, M. C. S., Resende, A. V., Polidoro, J. C., Bernadi, A. C. C., \& Oliveira, F. A. (2010). Potássio, cálcio e magnésio. In L. I. Prochnow, V. Casarin, \& S. R. Stipp (Eds.), Boas práticas para uso eficiente de fertilizantes (pp. 137-191). Piracicaba, SP: IPNI.

Biagiotti, G., Valeri, S. V., Cruz, M. C. P., Vasconcelos, R. T. (2017). Fertilização potássica na implantação de Corymbia citriodora (Hook.). Scientia Forestalis, 45(113), 129-137. https://doi.org/10.18671/scifor. v45n113.12

Bonfim-Silva, E. M., \& Monteiro, F. A. (2010). Nitrogênio e enxofre na adubação e em folhas diagnósticas e raízes do capim-braquiária em degradação. Revista Brasileira de Zootecnia, 39(8), 1641-1649. https://doi.org/10.1590/S1516-35982010000800004

Carvalho, P. E. R. (1994). Espécies florestais brasileiras: Recomendações silviculturais, potencialidade e uso da madeira (p. 640). Colombo: EMBRAPA-CNPF; Brasília, DF: EMBRAPA-SPI.

Ciamporová, M. (2002). Morphological and structural responses of plant roots to aluminium at organ, tissue, and cellular levels. Biologia Plantarum, 45(2), 161-171. https://doi.org/10.1023/A:1015159601881

Ciriello, V., Guerrini, I. A., \& Backes, C. (2014). Doses de nitrogênio no crescimento inicial e nutrição de plantas de guanandi. Cerne, 20(4), 653-660. https://doi.org/10.1590/01047760201420041445 
Costa, L. N., Morais, P. L. D. de, Leite, G. A., Almeida, M. L. B., Miranda, M. R. A. de, \& Fernandes, P. L. de O. (2017). Influência da adubação potássica na qualidade e no potencial antioxidante do sapoti em diferentes estádios de desenvolvimento. Revista Ceres, 64(4), 419-425. https://doi.org/10.1590/0034-737x2017640 40011

Costa, M., Tonini, H., Dias, C., \& Iwata, B. (2012). Fertilization during the establishment of a Eucalyptus camaldulensis plantation in the northern Brazilian Amazon. Revista Agroambiente, 6(2), 91-101. https://doi.org/10.18227/1982-8470ragro.v6i2.791

Debbarma, J., Alila, P., Banik, M., Mandal, A. K., \& Chakma, A. (2017). Effect of different levels of nitrogen and potassium on the growth and yield of Pepino (Solanum muricatum Ait.). The Pharma Innovation Journal, 6(11), 817-821.

Epstein, E., \& Bloom, A. J. (2006). Nutrição mineral de plantas: Princípios e perspectivas (2nd ed., p. 403). Londrina: Planta.

Frazão, J. J., Benites, V. de M., Ribeiro, J. V. S., Pierobon, V. M., \& Lavres, J. (2019). Agronomic effectiveness of a granular poultry litter-derived organomineral phosphate fertilizer in tropical soils: Soil phosphorus fractionation and plant responses. Geoderma, 337(5), 582-59. https://doi.org/10.1016/j.geoderma.2018. 10.003

Gomes, I. B. (2012). Respostas ecofisiológicas de plantas jovens de Bertholletia excelsa H. B. submetidas à fertilização em plantio homogêneo (Master's thesis, National Research Institute of the Amazon, INPA, Manaus, Brazil).

Han, K., Zhou, C., Sheng, H., Yang, Y., Zhang, L., Wang, L., ... Li, Z. (2015). Agronomic improvements in corn by alternating nitrogen and irrigation to various plant densities. Agronomy Journal, 107(1), 93-103. https://doi.org/10.2134/agronj14.0335

Jesus, M. S., Fernandes, L. A., Fonseca, F. S. A., Rocha, S. M. G., \& Martins, E. R. (2016). Crescimento e composição do óleo essencial de mudas de Eucalyptus globulus (Labill) adubadas com nitrogênio e potássio. Caderno de Ciências Agrárias, 8(2), 1-8. https://periodicos.ufmg.br/index.php/ccaufmg/article/view/2898

Laclau, J. P., Almeida, J. C. R., Gonçalves, J. L. M., Saint-André, L., Ventura, M., Ranger, J., ... Nouvellon, Y. (2009). Influence of nitrogen and potassium fertilization on leaf lifespan and allocation of above-ground growth in Eucalyptus plantations. Tree Physiology, 29(1), 111-124. https://doi.org/10.1093/treephys/tpn010

Lima, R. M. B. de. (2004). Crescimento de Sclerolobium paniculatum Vogel na Amazônia, em função de fatores de clima e solo (Doctor's thesis, Federal University of Paraná, Curitiba, Paraná, Brazil).

Lukowiak, R., Grzebisz, W., \& Sassenrath, G. F. (2016). New insights into phosphorus management in agriculture-A crop rotation approach. Science of the Total Environment, 542(Part B), 1062-1077. https://doi.org/10.1016/j.scitotenv.2015.09.009

Marschner, P. (2012). Marschner's mineral nutrition of highter plants (3rd. ed., p. 615). San Diego: Academic Press. https://doi.org/10.1016/B978-0-12-384905-2.00015-7

Mendes, H. S. J., Paula, N. F. de, Scarpinatti, E. A., \& Paula, R. C de. (2013). Respostas fisiológicas de genótipos de Eucalyptus grandis $\times$ E. urophylla à disponibilidade hídrica e adubação potássica. Cerne, 19(4), 603-611. https://doi.org/10.1590/S0104-77602013000400010

Mengel, K., \& Kirkby, E. A. (2001). Principles of plant nutrition (5th ed., p. 849). Dordrecht: Kluwer Academic Publishers. https://doi.org/10.1007/978-94-010-1009-2

Moro, L., Gatiboni, L. C., Simonete, M. A., Cassol, P. C., \& Chaves, D. M. (2014). Resposta de Pinus taeda com diferentes idades à adubação npk no planalto sul catarinense. Revista Brasileira de Ciência do Solo, 38(4), 1181-1189.

Nascimento, H. H. C. do., Pacheco, C. M., Lima, D. R. M. de, Silva, E. C. da, \& Nogueira, R. J. M. C. (2014) Aspectos ecofisiológicos de mudas de Hymenaea courbaril L. em resposta a supressão de N, P e K. Scientia Forestalis, 42(103), 315-328.

Oliveira, J. B., Vale, A. T., \& Melo, J. T. de. (2006). Caracterização mecânica e contração da madeira de Sclerolobium paniculatum Vogel cultivado em um plantio homogêneo sob diferentes níveis de adubação. Ciência Florestal, 16(1), 89-97. https://doi.org/10.5902/198050981890

Raij, B. V. (1991). Fertilidade do solo e adubação (p. 343). Agronômica Ceres: Potafos. 
Rodrigues, M., Pavinato, P. S., Withers, P. J. A., Teles, A. P. B., \& Herrera, W. F. B. (2016). Legacy phosphorus and no tillage agriculture in tropical oxisols of the Brazilian savanna. Science of the Total Environment, 542(Part B), 1050-1061. https://doi.org/10.1016/j.scitotenv.2015.08.118

Rohácek, K. (2002). Chlorophyll fluorescence parameters: The definitions, photosynthetic meaning, and mutual relationships. Photosynthetica, 40(1), 13-29. https://doi.org/10.1023/A:1020125719386

Route, G. R., \& Samantaray, P. Das. (2001). Aluminium toxicity in plants: A review. Agronomie, 21, 3-21. https://doi.org/10.1051/agro:2001105

Ryan, M. G. (2010). Factors controlling Eucalyptus productivity: How water availability and stand structure alter production and carbon allocation. Forest Ecology Management, 259(9), 1695-1703. https://doi.org/10.1016/ j.foreco.2010.01.013

Santos, E. F., Araújo, É. de O., \& Camacho, M. A. (2015). Eficiência no uso de nitrogênio por genótipos de algodoeiro arbóreo sob aplicação de fósforo. Revista de Ciências Agrárias, 58(4), 357-364. https://doi.org/ $10.4322 /$ rca. 1892

Sarcinelli, T. S., Lynch, L. De S., Ribeiro Jr., E. S., \& Dias, L. E. (2004). Crescimento de mudas de taxi-branco (Sclerolobium paniculatum Voguel) em resposta à omissão de macronutrientes. Revista de ciências Agrárias, 42, 109-124.

Schumacher, M. V., Viera, M., Londero, E. K., Calil, F. N., Lopes, V. G., \& Witschoreck, R. (2013). Crescimento da acácia-negra em resposta a aplicação de nitrogênio, fósforo e potássio. Cerne, 19(1), 51-58. https://doi.org/10.1590/S0104-77602013000100007

Silva, E. C., Nogueira, R. J. M. C., Silva, M. A., \& Albuquerque, M. B. (2011). Drought Stress and Plant Nutrition. Plant Stress, 5(1), 32-41.

Silva, P. H. M., Poggiani, F., Libardi, P. L., \& Gonçalves, A. N. (2013). Fertilizer management of eucalypt plantations on sandy soil in Brazil: Inicial growth and nutrient cycling. Forest Ecology and Management, 301, 67-78. https://doi.org/10.1016/j.foreco.2012.10.033

Souza, R. S. de, \& Chaves, L. H. G. (2016). Doses de fósforo e potássio no desenvolvimento da cultura de Crambe abyssinica. Revista Verde de Agroecologia e Desenvolvimento Sustentável, 11(2), 71-75. https://doi.org/10.18378/rvads.v11i2.4298

Yamamoto, Y., Kobayashi, Y., Devi, S. R., Rikiishi, S., \& Matsumoto, H. (2002). Aluminum toxicity is associated with mitochondrial dysfunction and the production of reactive oxygen species in plant cells. Plant Physiology, 128(1), 63-72. https://doi.org/10.1104/pp.010417

\section{Copyrights}

Copyright for this article is retained by the author(s), with first publication rights granted to the journal.

This is an open-access article distributed under the terms and conditions of the Creative Commons Attribution license (http://creativecommons.org/licenses/by/4.0/). 